\title{
ÉDIPO: ESTRATIGRAFIAS DA MEMÓRIA HERÓICA
}

\author{
FRANCISCO MARSHALL* \\ Instituto de Filosofia e Ciências Humanas \\ Universidade Federal do Rio Grande de Sul
}

\begin{abstract}
RESUMO: A partir do exame da dimensão histórica e memorialista do mito do herói, estuda-se os diversos níveis de representação histórica presentes no mito de Édipo, conforme tratado por Sófocles. Além de explorar o tópico conceitual "mito do herói", o artigo compara o imaginário heróico entre as tragédias Édipo Tirano e Édipo em Colono.
\end{abstract}

PALAVRAS-CHAVE: mito; mito do herói; memória histórica; Sófocles; Édipo.

A memória dos heróis na Grécia antiga é um fenômeno cultural de dimensões extraordinárias, capaz de referenciar a percepção de uma vasta gama de fenômenos sociais, políticos, religiosos, éticos e psicológicos. Como rei, guerreiro, sábio, cavaleiro, atleta, vate, artista, daimon, patrono, líder ou magnata, habitando em palácio, altar, necrópole ou montanha, expresso em versos, pinturas, esculturas, ritos e nas mais variadas narrativas, o herói está presente em todas as páginas e cenários do mundo clássico. Ao falarmos de heróis, referimos nomes e endereços por vezes bastante precisos, mas tocamos também em todos os outros registros comportados pela memória heróica, em sua morfologia complexa, os quais fornecem a inteligibilidade e a comunicabilidade da figura histórica, e se acumulam como um grande léxico interpretativo. Esta memória corresponde também a diferentes cenários históricos, diferentes estéticas e afetividades, diferentes comunidades idiomáticas, que se vão amalgamando em torno do evento rememorado, formando estratigrafias da memória: diferentes camadas, com propriedades distintas, mas localizadas em torno do mesmo fenômeno. A memória heróica da tragédia grega é já o resultado de diversas camadas de experiência histórica que fornecem a Ésquilo, Sófocles e Eurípides o léxico de imagens e vocabulários com que representar o herói.

Embora aspectos do mito heróico estejam figurados já nas civilizações do antigo Oriente próximo, foi na Grécia que esta categoria atingiu seu máximo de- 
senvolvimento. O melhor indício da relevância helênica do mito heróico deu-nos Hesíodo, que ao inserir em sua narrativa de Os trabalhos e os dias o tópico tradicional do mito das idades, emprestado de antigas civilizações orientais, viu-se convidado a inserir nas quatro idades metálicas e suas progênies um quinto estrato, a idade dos heróis, em que teria vivido uma gente "mais justa e mais corajosa / raça divina de homens heróis e são chamados / semideuses, geração anterior à nossa na terra sem fim" (Hesíodo, Os trabalhos e os dias, vv. 158-160).

Talvez poucos contemporâneos de Hesíodo tenham percebido este acréscimo e feito a devida análise comparativa, valorizando a relevância da memória heróica no imaginário grego, chancelada por um rapsodo talentoso e consagrada por muitos outros cantores. Hesíodo, entretanto, percebeu que seria impossível contar a história de homens e Deuses da Grécia sem dar destaque àqueles semideuses, protagonistas dos grandes cantos míticos, e situá-los em uma idade de glória que precede a idade de ferro em que vivia e se lastimava o poeta. Merece destaque este efeito de vinculação histórica, que situa a estirpe heróica como antecedente imediato dos homens da idade férrea, intensificando sua historicidade devido à colação de parâmetros tangíveis - o mundo contemporâneo de Hesíodo, pós-heróico.

No horizonte histórico homérico, a memória heróica compreendia um conjunto de fenômenos que expressavam a primazia social de uma classe de homens guerreiros, líderes dotados de propriedades e prestígio, protagonistas da vida social presentes na guerra e nos banquetes, na ágora e no comando de naus, em templos, altares e palácios, alcovas e sepulturas. Por conseguinte, a memória heróica refletiu em seu desenvolvimento histórico algo da história social desta classe de homens, suas crises e reaparições, suas funções sociais e imagens, desde a época homérica até momentos avançados da história clássica, inclusive nos mundos helenístico, romano e tardo-antigo. No mundo homérico, o endereço social do herói é muito claro: habita palácios. Uma vez que a saga homérica é matriz de valores e referências para o mito do herói helênico, será natural esperarmos alguma reverberação desta identidade entre mito e sociedade (i.e., herói e aristocracia) também nos outros contextos diretamente tributários do mito homérico.

Mas se a projeção da grandeza e da excelência ética e o reconhecimento desta grandeza, por meio da fama épica e do culto, consagraram a imagem dos heróis, protagonistas da história homérica, por outro lado, esta exposição brilhante concedeu objetividade histórica a uma classe de pessoas que passará a ser alvejada a partir da época arcaica. $O$ aristocrata, evidente em muitas imagens, tornouse alvo fácil em uma época de antagonismos sociais e de crítica da tradição, no cenário de crises abertas a partir do século VII a.C.. 
As novas lideranças nas cidades - os tiranos - concebiam estratégias de Estado freqüentemente contra a aristocracia tradicional, perseguindo casas concorrentes e promovendo políticas populares. Neste mesmo cenário, entre os séculos VII e VI a.C., cristalizaram-se diversos tipos de identidade coletiva, profissionais (ceramistas, armadores, marinheiros), militares (hoplitas) e religiosas (cultos rurais, entusiásticos e iniciáticos), contrariando em muitos pontos as hegemonias tradicionais (heróicas e aristocráticas). No contexto de crítica social da idade arcaica grega, uma nova camada de afetividades se acrescentou à figura histórica do herói, ampliando o estranhamento e refletindo o enfraquecimento das aristocracias tradicionais. Temidas e censuradas por uma mobilização coletiva, figuras proeminentes passaram a ser vistas como corpos estranhos a serem expelidos do convívio a bem da saúde pública.

Esse mundo já não era cenário de Odisseu e Aquiles. Todavia, em que pese a crise da aristocracia, o mito do herói permanece eficiente como acervo de representações imaginárias com que se pensa a ação histórica, não só como fonte de valores éticos, mas especialmente como referência para se pensar a liderança, pois traz consigo desde sempre problemas relativos ao relacionamento do líder com as coletividades, em seus aspectos positivos e negativos. Embora presente já em Gilgamesh, este tema foi maximamente explorado pela tragédia e transmitido à tradição como um ensaio de filosofia política, dramatizada.

A reflexão sobre herói e coletividade, a pergunta sobre as relações entre a excelência de indivíduos e a salvaguarda da harmonia coletiva não se esgotou na estigmatização do herói, mas permaneceu como um dos problemas do pensamento político. Este foi um conflito básico em cidades que se institucionalizaram como repúblicas (democracias) mas preservaram na educação e na cultura a base ética aristocrática. Lembre-se o lamento de Heráclito (c. 550 a.C.) pela atitude de seus conterrâneos, que teriam, segundo ele, expulsado o melhor dos homens:

É justo que todos os efésios adultos sejam mortos e os menores abandonem a cidade, eles que baniram a Hermodoro, seu melhor homem, dizendo: nenhum de nós será o melhor; mas se alguém o for, então que seja alhures e entre outros. (Heráclito, fragmento 121, trad. Emanuel Carneiro Leão)

Esta passagem dá testemunho da reação coletiva contra um homem notável, mas o ponto de vista de Heráclito, ao lastimar o aristocrata proscrito ${ }^{1}$, espelha antes a sobrevivência de várias ideologias apologéticas do herói, que sucedem no 
tempo desde a Grécia até os dias atuais, como um conjunto de imaginários e de afetividades do poder. Neste imaginário, o herói desfruta de um papel positivo, até mesmo necessário para o bem da coletividade, que ele pode eventualmente salvar com sua fortaleza extraordinária. Há uma larga produção de textos, imagens plásticas, espetáculos e rituais sustentando esta visão do herói, concedendo-lhe sempre um lugar honorífico; arte-criadores sempre vendem bem este tema. Além de muitos regimes e revoluções, alguns projetos políticos recentes, como o positivismo e o fascismo, manipularam diretamente este imaginário, muito caro também a demagogos e marqueteiros. Mesmo na Grécia, a crítica os ataca e as cidades os expulsam, mas os heróis e suas tradições resistem, seja nas cidades oligárquicas ou nas casas dos campeões atléticos em que canta Píndaro, seja em variados cultos que não cessam de surgir ou mesmo dentro da própria pólis democrática. O herói está abrigado junto a diversas atitudes e instituições da cidade, no contexto em que se digladiam aristofilia e aristofobia, em diferentes momentos.

Heráclito não aceita que alguém dotado de virtudes superiores seja expulso da cidade, mas é precisamente isso que a coletividade ora visava; já visava eventualmente, no mundo arcaico, mas o fez com mais ganas e base legal no século $\mathrm{V}$ a.C., com o emprego do ostracismo em Atenas. Leis e costumes expulsando pessoas notáveis apresentavam-se então como soluções de caráter profilático, sanando poluções e restaurando o equilíbrio no corpo social. Mas este banimento, mesmo quando realizado de acordo com um protocolo jurídico positivado (caso do ostracismo) e/ou por injunções políticas contextuais, mimetizava um ritual purificador, em que o transgressor e ameaça é sacrificado, restaurando-se a força e a confiança da coletividade. Como René Girard (1986) nos demonstra, este papel ritual se intensifica na mesma proporção em que se fortalece a comunidade - é um rito eminentemente comunitário. Neste rito político, o herói (ou o proto-herói) assume o papel de vítima expiatória, e é visado pela sensibilidade coletiva.

Ao examinar a relação entre herói e cidade, e ponderar as transformações do estatuto heróico, é interessante comparar os destinos do herói Édipo em Homero e em Sófocles. Em Homero, o monarca prossegue reinando em Tebas, ao passo que na tragédia de Sófocles ele é expulso da cidade, sob os efeitos de um decreto do próprio autocrata (vv. 224-54) que deu força legal ao antigo costume de se proscrever o assassino miasmático. O Édipo homérico permanece, o sofocleano parte; em Eurípides (Fenícias, 1543), Édipo teria ficado em uma masmorra no palácio. Estaria aí um indício da diferença de estatuto jurídico e de mobilização comunitária, de efeito nulo em Homero, mas decisiva para Sófocles? Como pôde permanecer o Édipo homérico? Há neste caso, ademais, outro problema sério: como fica o 
efeito negativo da polução, as conseqüências de sua permanência no território? Seria a força do poder monárquico tida como superior e soberana sobre os princípios religiosos, a ponto de eliminar, desprezar ou subordinar as implicações de uma presença miasmática? Ou seria o estatuto heróico de Édipo suficiente para justificar sua permanência, malgré tout? Ou, ainda, prevaleceria sua legitimidade dinástica, como soberano evidenciado pertencente à casa real, a garantir-lhe o trono independentemente de qualquer injunção moral ou legal?

$\mathrm{Na}$ época de Pisístrato e também no século de Péricles, muitos banimentos ocorreram ou foram requisitados em Atenas, algumas vezes com justificativa ou pretexto religioso. Estas proscrições e ameaças visavam sobretudo aos aristocratas, que talvez não apreciassem tanto tal perspectiva; entre o suicídio de classe de Péricles e o populismo de Címon, a aristocracia precisava defender-se e mostrar-se útil ao povo. Por outro lado, a atitude, de efésios e atenienses, proscrevendo lideranças, mantinha aceso o debate inaugurado por Heráclito: será mesmo maléfico o efeito da presença heróica? Os heróis são mesmo corpos nocivos, ou são forças benéficas?

A questão epistemológica que não podemos esconder é relativa à possibilidade de neste contexto associar herói e aristocracia e, em um segundo momento, pensar conjuntamente herói, aristocrata e tirano - o líder que se destaca, o notável que é diferente do povo. Esta discussão envolve categorias religiosas, ligadas ao culto de heróis, e políticas, ligadas ao imaginário aristocrático diretamente relacionado ao herói, bem como as relações da coletividade com suas lideranças. Esta questão parece ter preocupado muito a Sófocles, em suas implicações religiosas e políticas. $\mathrm{O}$ alcance de sua reflexão pode ser especialmente percebido cotejandose os problemas e alternativas formulados em duas obras cruciais, que conhecemos como Édipo Tirano e Édipo em Colono. A territorialidade do herói está no centro de ambas. Na primeira, assistimos à transição do protagonista, que abre a ação trágica junto aos altares de seu palácio, no âmago da cidade, onde Édipo recebe o cortejo de suplicantes; ao final, no êxodo, Édipo dirige-se ao desterro, devido à força de uma proclamação que visava a expelir do território da cidade o assassino miasmático. Reconhecendo e acatando seu destino trágico, sob pressão de Creonte, Édipo deixa Tebas, e vai viver fora da cidade. A tragédia Édipo Tirano é também uma tragédia do poder, que exibe as várias crises por meio das quais um herói triunfante e governando termina por perder o poder e exilar-se da cidade. Já na tragédia Édipo em Colono, encenada cerca de 23 ou 25 anos após o primeiro Édipo, o herói reaparece vagando nos arredores de Atenas, e todo o drama se desenvolve em torno do destino de seu corpo, reivindicado para Tebas por Polinices, um destino que Édipo recusa com veemência, oferecendo a Teseu e a Atenas a graça de abrigar seu cadá- 
ver e, com ele, as forças benfazejas emanadas em defesa do território. A argumentação de Édipo junto a Teseu procura esclarecer o mistério desta natureza ambivalente, em que sua persona miasmática, que vaga como mendigo errante, perseguido dos Deuses e hostilizado por seus conterrâneos, pode converter-se em beneplácito para o local que o acolher em sua morte. Ao final, Sófocles compõe o quadro luminoso - um dos momentos mais sublimes de toda a tragediografia clássica - em que Édipo marcha para seu destino apoteótico, conduzido por Teseu para o local em que este rei testemunhará "uma aparição espantosa, insuportável" (v. 1650-1); como diz o mensageiro, "seu fim esplende maravilhoso entre os que perecem" (v. 1664-5). E este esplendor converte-se em força para a comunidade ateniense, coincidentemente, no burgo em que nasceu Sófocles, Colono.

No cotejamento das tragédias Édipo Tirano e Édipo em Colono, destaca-se nesta a veemência e a ênfase com que Édipo argumenta por sua inocência, ao replicar ao escárnio acusatório de Creonte (vv. 960-999). Esta passagem, e a própria concepção deste drama, produz forte impressão de que Sófocles estaria comentando e esclarecendo sua tragédia anterior; estaria, talvez, defendendo Édipo dos rumores produzidos após a encenação da primeira obra, e esclarecendo o público quanto a aspectos da compreensão do mito que podem ter escapado aos atenienses. Sófocles deixa antever a presença de uma opinião pública inculpatória, acusando Édipo por erros que justificariam seu destino trágico. A estas opiniões, o tragedista responde afirmando com argumentos enfáticos a inocência objetiva de Édipo, em termos que reverberam claramente a jurisprudência Ática. Édipo matou involuntariamente, logo não pode ser condenado, e mereceria a compreensão mesmo de seu finado pai, Laio. Deu-se o mesmo com o incesto, involuntário, nenhum dos dois sabia. Édipo foi vitimado por antigo ódio divino dirigido contra sua raça, e nada mais. Uma vez que este libelo de inocência depende de uma conseqüente responsabilização no âmbito divino, a tragédia consigna com idêntica ênfase a natureza numinosa do destino de Édipo. É como se Sófocles dissesse: não foi o destempero da cólera nem a maldade do espírito, Édipo errou porque é um grandíssimo herói, e suporta seu destino. Assim, Édipo em Colono, tragédia póstuma, não é apenas obra de Sófocles, mas mais precisamente de Dexion, o nome com que o Sófocles sacerdote de Asclépio foi venerado heroicamente após sua morte. Édipo Colono é a tragédia por excelência para ilustrar o estatuto do culto heróico no século $\mathrm{V}$ a.C. em Atenas, especialmente as concepções vigentes no círculo de Sófocles, uma elite prestigiosa, que transita entre as artes e o Estado. Trata-se, aqui, de uma apologia do culto heróico.

O tema do cadáver heróico, que se destaca no Édipo em Colono, já esteve na pauta de Sófocles muito anteriormente, na tragédia Antígona, que na interpre- 
tação John Jones (1981) estaria mimetizando os traumas da comunidade ateniense após as reformas de Clístenes. Este reformador, entre outras revoluções, reordenou o território a partir de nova estrutura do culto heróico, consistente com relação ao padrão decimal imposto à organização urbana e política (Vernant, 1992). Esta desacomodação, que atingiu a inscrição do indivíduo na pólis, ritualísticas quotidianas e a própria cultura funerária, teria legado um sentimento de desconforto, especialmente sensível junto às casas aristocráticas, diretamente visadas por Clístenes. Este tema parece ocupar posição central no repertório de problemáticas abordadas por Sófocles, ilustrando o modo simultaneamente religioso e políticocomunitário com que este pensa a questão heróica e, dentro dela, a questão do corpo do herói. Tal tema aparece também na tragédia Ájax e de certo modo também em Filoctetes.

No Édipo Tirano, a questão do território, presença e banimento do herói adquire ainda outros contornos mais precisos, relacionados à ameaça ao poder e às estratégias de defesa e ataque do soberano, no momento em que se fragiliza seu estatuto político. Para o combate ao miasma que empestava Tebas, Édipo publica um decreto que mimetiza uma categoria jurídica ateniense (Greiffenhagen), cujo principal objetivo era proscrever o responsável pelo regicídio que ora se apura. No momento em que Édipo interpretar a falta de colaboração e as acusações de Tirésias como conspiração, e associar Creonte a esta cabala, a cura da cidade visada por Édipo passará a implicar em necessariamente proscrever Creonte. Além disso, há o temor de que ele próprio, Édipo, fosse expulso da cidade, como resultado da ação subversiva do vate e do tio/cunhado. A proscrição de Creonte só é evitada devido a uma mobilização do Coro e a uma intervenção de Jocasta, no momento em que entram em ação todas as estruturas dinásticas do poder em Tebas. Ao examinar as ações de Édipo face à hipotética conspiração, o helenista alemão Karl Reinhardt $(1971,144)$ observa que há uma ameaça pairando no ar, intranqüilizando Édipo até que ele a faça colar-se em Creonte e em Tirésias, suspeitos e culpados no universo de aparentes certezas em que transita. Nesta leitura, a suspeita ou ameaça é como que entificada, sendo necessário a Édipo fixá-la em algum ponto externo, que o salve e garanta sua permanência. A leitura de Reinhardt detecta de modo instigante as homologias entre processo político e ritualística arcaica. A história do direito ateniense e a própria mecânica do ostracismo, além da fenomenologia da culpabilidade em Sófocles, esclarecem bem quanto à pertinência desta leitura do imaginário clássico.

O uso dramático do tema do banimento, associado à presença do corpo do herói, reverbera algo da instabilidade política e do estatuto do indivíduo notável 
(herói ou aristocrata) na pólis. Neste sentido, a problemática maior da crítica do herói e seus valores no mundo da pólis clássica, nos termos em que Vernant define sua sócio-antropologia da tragédia, reflete não apenas um ambiente geral, mas especialmente as reações de uma perspectiva particular - a de Sófocles, sem que se despreze a sua localização religiosa e política. Em sua tragediografia, no Édipo Tirano e na Antígona, em particular, é notável a sensibilidade para o tema correlato da tomada do poder. Em várias passagens notamos a descrição e denúncia do modus operandi conspiratório, com o uso de brigadas, de suborno com dinheiro e de coligações como a de Tirésias e Creonte. Além de retomar um problema típico da vida política da era arcaica de Atenas (as diversas conspirações, o uso de dinheiro, traições e cabalas), Sófocles mimetiza e atualiza temores presentes também no seio da comunidade ateniense contemporânea, e o faz com acento ora político, ora religioso, ora político e religioso.

No tratamento dado à figura edípica, especialmente na comparação entre suas duas tragédias sobre Édipo, Sófocles utiliza uma noção de ethos discordante da noção com que Aristóteles (na Poética) conceitua o caráter agente do drama, formado, para ele, a partir das ações - e para Aristóteles não há caráter sem ação. Para Sófocles, o herói é uma potência sagrada, dotada de identidade, e mesmo que as ações expressem esta grandeza e as várias perplexidades de seu convívio comunitário, subjaz uma definição de natureza, em que a figura heróica sobreleva-se acima da teoria do espetáculo e das vicissitudes da ação no drama.

Por fim, cabe considerar que ao estudarmos o imaginário clássico através da tragediografia, neste caso a de Sófocles, tocamos sem dúvida em um acervo de valores e representações de absoluta relevância histórica, seja pelo modo com que recebe e processa a tradição, seja pelo impacto que tem na comunidade por meio do espetáculo dramático no teatro de Dioniso e de sua reprodução oral e escrita. $\mathrm{O}$ estudo do imaginário heróico, porém, não pode prescindir do inventário das demais categorias eficientes no processo de leitura de seu público alvo, e do modo com que um grego do século $\mathrm{V}$ a.C., ao assistir à crítica à teimosia e isolamento do herói e ao testemunhar todos os impasses e padecimentos deste seu destino histórico, deve negociar a compreensão desta versão do mito e da lógica do drama a partir de um conjunto de referenciais que inclui a memória épica, a religiosidade tradicional, as crises éticas arcaica e clássica, a vida da cidade, uma iconografia riquíssima e suas versões do mito, entre outros referentes ativos, inclusive suas próprias visões (individuais ou micro-comunitárias) do mito. E muitos espectadores considerariam também o endereço social de onde Sófocles produz sua interpretação, algo perceptível imediatamente aos seus contemporâneos. 
Por todas essas razões de relevância histórica, o herói constituiu uma tópica de memória histórica complexa, dotada de múltiplas referências procedentes de diversas épocas e locais, cuja interpretação permite compreender diferentes aspectos da vida e da cultura grega. É por esta razão que adotei este título arqueológico, estratigrafia da memória heróica, visando a distinguir os diferentes componentes deste fenômeno, embora de fato a memória histórica, à diferença da arqueológica, não se imobilize em diferentes níveis sucessivos, mas mais freqüentemente opere por meio de amálgama e acúmulo, fazendo com que os dados de uma memória antiga se perpetuem e compareçam em fenômenos mais recentes, porém modulados em função de novas demandas contextuais. Uma estratigrafia revolvida, seria mais adequado referir.

A metáfora genética, por sua vez, com que se pode pensar a transmissão da tradição analogamente à transmissão dos caracteres, por genes dominantes e recessivos, permite referir mais sensivelmente a transmissão do material mnemônico, pois distingue elementos que, mesmo inaparentes, estão preservados como código, como informação genética prestes a se tornar evento. Neste caso, porém, seria uma ilusão idealista tributar autonomia ao fenômeno, como se ele pudesse determinar, na vida histórica ou em nossa leitura distante, o que é predominante ou hegemônico. Ora, os efeitos de memória, tal qual muitos efeitos estéticos, caracterizam-se formalmente por envolver a interação de três campos referencias, ligados à emissão, à transmissão e à recepção de mensagens, momentos nos quais interferem diretamente variáveis de leitura pertencentes ao autor, ao meio social e histórico e ao leitor, o que implica considerar a possibilidade de processos de semiose, em que a interpretação da mensagem não coincide necessariamente com a intenção do emissor. Neste processo, perde-se a autonomia do fenômeno, mas ganha-se com a valorização da história e o reconhecimento das diversas variáveis produtoras de sentido.

A semiose do mito não se confunde absolutamente com a didática de uma mensagem unívoca, mas sim com a evocação de um conjunto de experiências constitutivas da mensagem transmitida e recebida, experiências que se abrigam na mensagem e se preservam como registros de percepção e interpretação dados ao espectador ou ao leitor, na Grécia como no presente momento. 


\section{Notas}

* Prof. Dr. do PPG História e Coordenador do Núcleo de História Antiga do IFCH-UFRGS, autor de Édipo Tirano, a tragédia do saber (Porto Alegre / Brasília: EdUFRGS / EdUnB, 2000).marshall@ufrgs.br.

1 Veja-se também frgt. 29 ("uma coisa a todas as outras preferem os melhores: a glória sempre brilhante dos mortais; a multidão está saturada como o gado"), frg. 39 ("em Priene nasceu Bias, filho de Teutames, sua fama é maior do que a dos outros") e frgt. 49 ("um para mim vale mil, se for o melhor").

\section{REFERÊNCIAS BiBLIOGRÁFICAS}

DABDAB TRABULSI, José Antônio. Ensaio sobre a mobilização política na Grécia Antiga. Belo Horizonte, Editora UFMG, 2001.

GIRARD, RENÉ. A violência e o sagrado, São Paulo, Paz e Terra, 1998.

GREIFFENHAGEN, Gottfried. Der Prozess des Ödipus, in Hermes, v. 94, n. 2, p. 140-76, 1966.

HERÁCLITO. Fragmentos. Trad. Emmanuel Carneiro Leão. Rio de Janeiro, Tempo Brasileiro, 1980.

HESÍODO. Os trabalhos e os dias. Tradução de Mary Lafer. São Paulo, Iluminuras, 1990.

HOLUB, Robert. Reception theory: a critical introduction. London, Methuen, 1984.

HOMERO. Odisséia. Trad. de Carlos Alberto Nunes. São Paulo, Melhoramentos, 1962.

JONES, John. On Aristotle and Greek Tragedy. Stanford, Stanford University Press, 1980.

PEIRCE, Charles Sanders. Semiótica. São Paulo, Perspectiva, 1999.

REINHARDT, Karl. Sophocle. Paris, Les Éditions de Minuit, 1971.

TORRANO, Jaa. O Sentido de Zeus, São Paulo, Iluminuras, 1996.

VERNANT, Jean-Pierre. Mito e sociedade na Grécia antiga. Brasília e Rio de Janeiro, Editora Universidade de Brasília - José Olympio, 1992.

VERNANT, Jean-Pierre; VIDAL-NAQUET, Pierre. Mito e tragédia na Grécia antiga. São Paulo, Perspectiva, 1999. 
MARSHALL, Francisco. Oedipus: stratigraphies of heroic memory.

ABSTRACT: After considering the historical and memorialistic dimensions of the myth of the hero, we comment the several layers of historical representations belonging to the myth of Oedipus, as invented by Sophocles. Besides exploring the conceptual theme of "the myth of the hero", this paper compares the heroic imaginaries connecting the tragedies Oedipus Tyrannus and Oedipus in Colonus.

KEY WORDS: myth; myth of the hero; historical memory; Sophocles; Oedipus. 